\title{
ТАКТИКА ЭКСПЕРТНОГО ОСМОТРА ПРИ ПРОИЗВОДСТВЕ СУДЕБНОЙ ЭКОЛОГИЧЕСКОЙ ЭКСПЕРТИЗЫ ПОВЕРХНОСТНЫХ ВОД
}

\author{
Булавина Е.H. \\ Института судебных экспертиз по Восточно-Казахстанкой \\ Области (город Усть-Каменогорск), \\ Республика Казахстан
}

Экспертный осмотр является самостоятельной стадией судебно-экспертного экологического исследования. Целью экспертного осмотра является получение представлений о характере и состоянии объектов, маситабах антропогенного воздействия, выяснение условий способствующих распространению воздействия, а так же характер воздействия на компоненты окружающей среды. Экспертный осмотр включает в себя несколько самостоятельных его видов. В статье рассмотрены тактические действия эксперта при проведении экспертного осмотра.

Ключевые слова: тактика экспертного осмотра, экспертный осмотр, антропогенное воздействие, компоненты окружающей среды, причинно-следственные связи, источник антропогенного воздействия.

Водные ресурсы являются наиболее уязвимым звеном биосферы. Антропогенному вмешательству в большей степени подвержены поверхностные воды, чем остальные компоненты географичческой среды.

Причинами изменения состояния водоемов являются:

- изъятие водных и биологических ресурсов;

- загрязнение вод различными веществами;

- изменение режима функционирования водных экосистем.

Загрязнение представляет собой качественное истощение вод, основной причиной которого является поступление неочищенных или недостаточно очищенных стоков. Главные потребители воды - промышленность и сельское хозяйство, а также жилье кварталы крупных городов и населенных пунктов, расположенных по берегам водных объектов.

Любой вид хозяйственной деятельности человека, проводимой в значительных масштабах в бассейнах водных объектов, означает собой вмешательство в жизнь водоемов, которое может вызвать в их водном режиме существенные, а порой и коренные изменения.

В последние годы в Казахстане наблюдается устойчивый рост количества экологических правонарушений. К фракторам, увеличивающим эффективность совместной деятельности правоохранительных и природоохранных органов, относится использование специальных научных знаний в области экологии и смежных естественных наук при выявлении и рассмотрении экологических правонарушений в целях установления фактических обстоятельств негативного антропогенного воздействия на окружающую среду, в рамках судебной экологической экспертизы [1].

Адрес для корреспонденции: Булавина Елена Николаевна, заведующая лабораторией химических и биологических исследований Института судебных экспертиз по Восточно-Казахстанкой области (город Усть-Каменогорск), Республика Казахстан магистр гуманитарных наук, тел: 8 (777) 254 -97 -50, e-mail:Bulavina_e@bk.ru 
В Институт судебных экспертиз по Восточно-Казахстанской области, в рамках экологической экспертизы, поступают постановления о назначении экспертиз, объектами исследования, которых выступают загрязненные поверхностные воды. Цель - установление фактических обстоятельств антропогенного воздействия: источника воздействия, его механизма, характеристик источника загрязнения, масштабов, причинно-следственных связей, как с потенциальными источниками происшедших нарушений, так и с экологическим состоянием других компонентов окружающей среды на водном объекте.

Исследование экологического состояния поверхностных вод в рамках судебной экспертизы носит комплексный характер и представляет собой совокупность действий, производимых, в установленной законом форме, лицами, обладающими специальными научными знаниями, которые формулируют выводы и составляют заключение эксперта, связанное с исследованием антропогенного воздействия на поверхностные воды[2].

В процессе изучения представленных материалов в рамках проведения судебноэкологического исследования эксперту необходимо проанализировать информацию о происшедшем событии, результатах осмотра места происшествия и предварительного исследования последствий этого события (по установлению криминалистически значимой информации о самом преступном событии и его участниках), а также выявить пространственновременные и причинно-следственные связи. С учетом закономерностей механизма преступления, своего опыта и знаний, эксперту также необходимо сформировать мысленную модель механизма антропогенного воздействия на окружающую среду[3].

В настоящей статье рассмотрены особенности экспертного осмотра, как самостоятельной стадии судебно-экспертного экологического исследования поверхностных вод, содержанием которой является осмотр водного объекта, подвергшегося антропогенному воздействию. Цель экспертного осмотра - получение представлений о характере и состоянии объектов, масштабах антропогенного воздействия, выяснение условий способствующих распространению воздействия, характер воздействия на водный объект и компоненты окружающей среды.

Экспертный осмотр помогает решить нижеследующие важные задачи.

Основной задачей экспертного исследования является установление связи между загрязнением и имевшим место негативным антропогенным воздействием на компоненты окружающей среды, в том числе на поверхностные воды.

Промежуточными задачами, вытекающими из основной задачи судебно-экологической экспертизы состояния поверхностных вод являются:

- установление источника (способа, причины) негативного антропогенного воздействия;

- установление масштаба, обратимости (необратимости) и иных последствий негативного антропогенного воздействия;

- выявление условий и обстоятельств, способствующих усилению или ослаблению антропогенного воздействия;

- определение возможности восстановления исходного состояния поверхностных вод и разработка перечня необходимых реабилитационных мероприятий.

В зависимости от особенностей объектов принято различать:

- осмотр водного объекта;

- осмотр компонентов окружающей среды;

- осмотр путей распространения загрязнений; 
- осмотр источника или источников антропогенного воздействия.

Экспертный осмотр состоит из следующих этапов:

- рекогносцировочное исследование;

- заложение площадок пробоотбора и отбор образцов (проб) водного объекта (воды, донных отложений, почвы и растительности береговой линии и др.).

При обследовании места рассматриваемого события определяют:

- характеристику водоемов и водотоков;

- географические координаты места рассматриваемого события;

- метеоусловия;

- границы рассматриваемого события с применением рулетки и (или) дальномера;

- гидрологический режим водоема;

- характеристики рельефра;

- характеристики растительности (естественные или искусственные, записывается перечень видов древесно-кустарниковых и травянистых растений, произрастающих на береговой линии водного объекта и составляющих фритоценоз);

- наличие и характеристики различных сооружений и объектов;

- наличие признаков антропогенного воздействия в виде загрязнения водного объекта веществами, похожими на химические реагенты, отходы, минеральные и органические удобрения, нефть, нефтепродукты и др.;

- выявление признаков изменения береговой линии, захламления и др.

Тактика экспертного осмотра включает нижеследующие обязательные стадии:

Для определения пути следования эксперту рекомендуется составление «Маршрутного листа», с учетом изученных материалов, представленных на экспертизу, в котором схематично должен быть изображен план местности, события, прилегающие водотоки, указаны гидрологические посты отбора проб поверхностных вод (с учетом экологического мониторинга хозяйствующих субъектов, мониторинга государственных органов). При составлении маршрутного листа необходимо учесть:

1. Месторасположение предполагаемого субъекта антропогенного воздействия, а также требования к осмотру места происшествия.

2. Визуально уточнить границы места происшествия, узлы, которые необходимо осмотреть и последовательность осмотра.

3. Ознакомиться, прибыв на место события, по возможности с помощью специалистов государственных органов, сотрудников предприятия, с чертежами, схемами коммуникаций, картами и планами местности, правилами, регулирующими строительство и эксплуатацию предприятий, сооружений очистки и другими документами, характеризующими источник загрязнения, загрязняющие вещества и т.п.

Согласно рекомендациям по осмотру водного объекта, в ходе осмотра необходимо определить следующее:

- вид, название, назначение и хозяйственную характеристику водного объекта, земельного участка и т.д.;

- местонахождение водного объекта, прилегающего к нему земельного участка с признаками видимого загрязнения, его площадь (при определении размеров загрязнения используются карты, устойчивые ориентиры); рельеф местности, имеющий значение для осмотра водного объекта; 
- признаки, характеризующие свойства и состав воды (например, прозрачность воды, цвет, маслянистость, консистенцию, запах загрязняющих веществ и др.), признаки, характеризующие земельный участок (захламленность, наличие захоронения какими-либо отходами) и т.д.;

- количество видов погибших животных, местонахождение трупов животных;

- размер площади загрязнения водоема, в береговой полосе которого обнаружены погибшие растения; их вид и разновидность; минимальный и максимальный размер стеблей, листьев, соцветий; степень зрелости сельскохозяйственных культур;

- размер площади загрязнения земельного участка поверхностными водами и т.д.

- цвет различных частей растений; наличие признаков, характерных для загрязнения, степень их выраженности. При осмотре корнеплодов, оказавшихся под водой, необходимо определить их размеры, состояние (свежие, сгнившие, вялые), признаки гниения. При осмотре затопленных деревьев необходимо отмечать наличие некроза листьев и хвои, увядание листьев, оголение ветвей и всего дерева;

- имеются ли в зоне загрязнения или на участках местности, расположенных рядом с нею, следы, указывающие на источник загрязнения: следы транспортного средства на берегу или дне водоема и следы сброса или слива вредных веществ; гибель рыбы и иных водных организмов и растительности у места сброса вод из очистных сооружений конкретного предприятия.

Также определяются физические особенности поверхностных вод, ее границы, объем и водный режим водного объекта: положение рельефа, наличие и характер водоемов и водотоков, характеристики имеющихся строений и сооружений вблизи водоема. Определяется тип водотоков и водоемов (в основу разделения водоемов на типы и группы положены фракторы, характеризующие внешний и внутренний водообмен: проточность, глубина, площадь водной поверхности).

В обязательном порядке проводится фотосъемка водного и земельного участков, растительности, произрастающей по берегам участка, поврежденных растений.

При анализе особенностей окружающей среды, фриксируется наличие/отсутствие и характеристика возможных источников негативного антропогенного воздействия на участок местности: сбросы оборотной воды, сточных вод промышленных отходов фабрик, заводов, захламление берегов мусором или отходами различной природы, наличие каких-либо стоков, просадки поверхности, эрозии, загрязнение территории чем-либо, складирование на обследуемом участке строительных материалов, минеральных и органических удобрений, каких-либо химикатов, горюче-смазочных материалов и других веществ, могущих привести к загрязнению водного объекта.

Таким образом, с учетом вышеизложенного, можно прийти к заключению, что экспертный осмотр является самостоятельной стадией судебно-экспертного экологического исследования, который имеет как определенную конкретную цель, так и, с использованием специсрических тактических приемов, решает практические четкие и предметные задачи судебно-экспертных исследований.

\section{Список литературы}

1. Аверьянова Т.В. Судебная экспертиза Курс общей теории. Норма М.2008. 477с.

2. Криминалистика, под редакцией Белкина Р.С. М., Норма. М., 1999. 971с.

3. Комплексное криминалистическое исследование почв. Пособие для экспертов, ВНИИСЭ, М., 1978. 


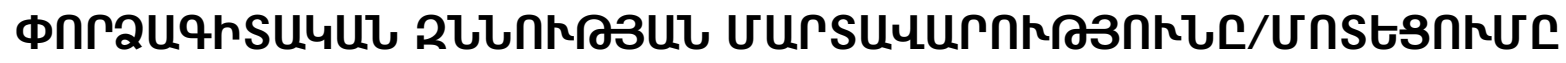

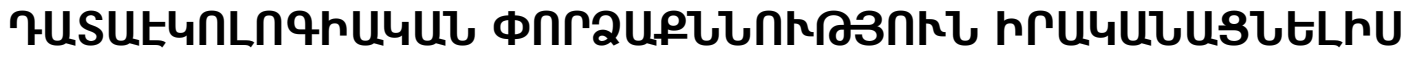

\section{คnцuц/hiu t.乙.}

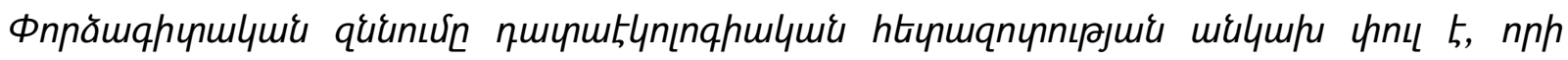

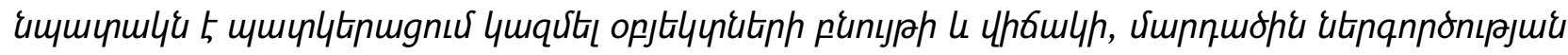

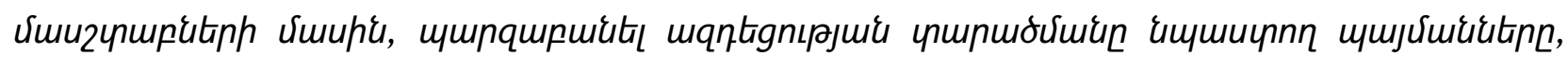

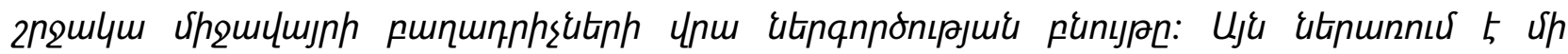

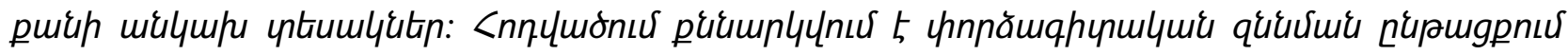

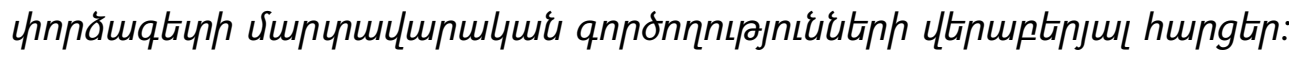

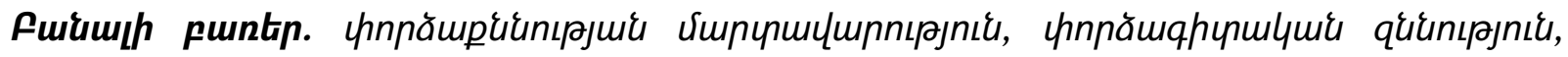

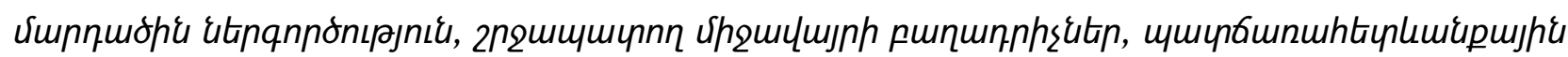

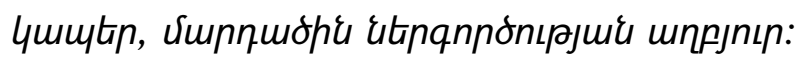

\section{TACTICS OF EXPERT EXAMINATION IN FORENSIC ENVIRONMENTAL EXPERTISE}

\section{Bulavina E.N.}

Expert examination is an independent stage of forensic ecological research. The purpose of the expert examination is to get an idea of the nature and condition of objects, the scale of anthropogenic impact, to clarify the conditions conducive to the spread of the impact, the nature of the impact on the components of the environment. The expert examination includes several independent types. The article deals with the tactical actions of an expert during an expert examination.

Keywords: tactics of expert examination, expert examination, anthropogenic impact, environmental components, causal relationships, source of anthropogenic impact. 